Ritchie, chairman of the Port of London Authority, in opposing the appointment of a Government commission of inquiry, which was the object of the debate, the substitution of half a dozen lock entrances at the barrage for an unimpeded fairway would mean obstruction to navigation and congestion of river traffic. On last year's figures, some 43,000 ships and 463,000 craft of various kinds would have to be locked through annually: the operation, he said, would be physically impossible. Moreover, the traffic is continually increasing. Other cogent reasons against entertaining the proposal were marshalled by the Earl of Erne, speaking for the Government, who explained the antipathetic views of the Ministries of Transport and Health and of the Board of Trade. In the issue of NATURE of December 7, 1935, we said that "an enterprise of this magnitude cannot be embarked upon without a considerable degree of risk to important interests, however propitious the general circumstances may appear to be" and, in yiew of the announcement that the estimated outlay is $4 \frac{1}{2}$ millions sterling, the need for a cautious attitude is greatly increased. Indeed, the objections already put forward are of so weighty a character that the trouble and expense of a public inquiry were considered unjustified by the Government and, under protest, the motion was withdrawn.

\section{A Suggested Botanic Garden in South Florida}

THE attempts to raise tropical plants under the extremely artificial conditions imposed by a temperate climate limits greatly the scope and usefulness of botanic gardens in the latitude of North America and Europe. The suggestion, therefore, which has been put forward, to found a tropical botanic garden in the United States, is warmly welcomed; for this will, in a way, bring the tropics within the reach of American botanists and plant breeders ("An Argument for a Botanical Garden in South Florida, to be called the Fairchild Botanical Garden", by Marjory S. Douglas. Kells Press, Coral Gables, Florida). The only possible site appears to be that suggested, which is in a frost-free area in the extreme south of Florida. This is close to Chapman Field, where the United States Department of Agriculture has its Plant Introduction Garden, with which the name of David Fairchild is so closely associated. Here are grown tropical plant introductions for the needs of the Department of Agriculture. It serves a very useful purpose in this respect, but it differs from a botanic garden in that it does not offer a permanent home to tropical trees and plants. It is strictly utilitarian and is not laid out with that æsthetic taste which one associates with botanic gardens and which has so large an educational effect on the visiting public.

Though the United States are fortunate in having a site for a tropical garden within their boundaries, and therefore of easy access to those who wish to visit it, the establishment of such a garden will be a costly undertaking. The soil of this region is extremely shallow, and much of it exists in crevices in the soft limestone which is often exposed on the surface. The principal agricultural industry in this area is fruit growing, and extensive orchards of mango, avocado and citrus have been established. Formerly, planting holes for the trees were blasted out of the soft rock, but it was found that the roots were strictly confined to the filled-in excavation thus formed. In recent years, soils have been made by 'scarifying' the surface with very heavy engine-drawn cultivators. The exposed soil with the limestone rubble is then collected into low, wide ridges along the top of which the trees are planted. It is found that a more extensive root system is thus formed, and the trees suffer much less from violent wind storms which occasionally visit this coast. Such calcareous soils are usually associated with the dry tropics, and it is possible that many species from such regions may thrive here, but in the humid tropics, which are so rich in their floras, the soils are generally acid and contain very little lime and, though many species of palms with their peculiar root system may be able to adapt themselves to local soil conditions, it is a different matter for many evergreen, broad-leaved species. To obtain the desired luxuriant tropical growth it may, therefore, be necessary to transport suitable soils in large quantities in which to grow such trees and plants, and this - if it proves to be necessary on an extensive scale-requires generous contributions towards the funds for founding these tropical botanic gardens.

\section{Central Asiatic Gold Mines of the Bronze Age}

THE sources from which prehistoric peoples obtained their minerals and other raw materials of industry afford valuable clues to their intercourse and cultural and economic contacts. A new source of gold in Central Asia is reported in the announcement of a discovery of prehistoric workings at Kazakhstan by a Russian expedition sent out by the Soviet Government (Soviet Union Year Book Press Service). The mines had been worked by a large number of workmen who used some implements of bronze, but for the most part of stone and the bones of animals. There were no traces of iron. Near the shafts were primitive ore-crushing plants, consisting of stone slabs and hammers. Two skeletons of these bronze age miners were found, who had met their death by a fall of the roof. On one of the skeletons was a necklace of glass and clay beads and in one hand was a bronze chisel and in the other a stone hammer. They were not Mongolian, as was indicated by their skulls. The mines were $0.75 \mathrm{~m}$. wide and 20-25 m. deep. They were connected by underground passages $100-150 \mathrm{~m}$. long. These passages had natural ventilation, and for illumination it is probable that fat in shallow bowls was employed. Some of these bowls have been found. Stone cross pieces were used as props. Polished slabs and triangles of stone have been found which appear to have been used on the steppes of Kazakhstan as sign-posts to guide caravans on their way to the mines. The slabs were orientated and polished on the eastern side. The Soviet Government is sending out another 